\title{
What Goes Around, Comes Around: The Manifestation of Peripeteia in Maugham's The Unconquered
}

\author{
Sina Movaghati \\ Kharazmi University, Iran \\ Received: 08-09-2016 \\ Accepted: 04-10-2016 \\ Published: 31-10-2016 \\ doi:10.7575/aiac.ijclts.v.4n.4p.57 \\ URL: http://dx.doi.org/10.7575/aiac.ijclts.v.4n.4p.57
}

\begin{abstract}
The aim of this article is to elucidate how the British novelist, William Somerset Maugham, exploited the dramatic devices such as Peripeteia and Anagnorisis as the focal devices in his short fiction. The short story, The Unconquered, is selected to pinpoint how Maugham set the stage for the Peripeteic downfall of his protagonist; as a result, the whole plot of the story will be dissected in the light of Aristotelian's Peripeteia. Furthermore, the interconnection bond between Peripeteia and Anagnorisis, in correlation with the narrative structure, will be probed.
\end{abstract}

Keywords: Creatures of Circumstance, The Unconquered, Aristotle, Peripeteia, Anagnorisis

\section{Introduction}

William Somerset Maugham's last collection of short stories, Creatures of Circumstance (1947), is the riveting accounts of the dramas of love, jealousy, revenge, and murder, filled with eccentric Freudian cases and enigmatic detective stories. In the series, Maugham exploited many classical dramatic devices, in order to mount the tension, whilst keeping his reader on the hook. The Mother, A Woman of Fifty, Episode, The Point of Honour and The Unconquered are the short stories which the dramatic devices are used excessively. Markedly, the Unconquered can be viewed in the light of Aristotelian's Peripeteia and Anagnorisis. It should be noted that "before turning to the short story Maugham was a successful dramatist, and much of his best work reflects this earlier preoccupation" (Hanson 49); therefore, it would not be illogical to study one of his short stories in the light of a dramatic device.

What is so intriguing about the Creatures of Circumstances is that the whole plot of the narratives depends on a sole climactic moment, which usually happens at the end of the narratives. In Episode, as an instance, the whole plot of the story revolves around a love affair between a convict, Fred Manson, and a Draper's daughter, Gracie Carter. As the narrative comes to it ending, suddenly Fred understand that he does not love Gracie anymore, and like a sudden lighting flash, Gracie puts an end to her life, and the narrative is closed. To me, several other short stories of Maugham follow this same pattern; therefore, I aimed to do a reading of one of his works, which was in the collection, in order to elucidate Maugham's technique in writing his short fiction.

\section{Defining Peripeteia and Anagnorisis}

In its classical functional definition, Peripeteia is considered to be a literary device which can be utilized "in Drama or Narrative," and bespeaks "a reversal in fortune, either, as in comedy, the move from bad to good, or in tragedy from good to bad or, occasionally, from bad to worse" (Quinn 318). The term was first defined in Aristotle's Poetics, when the Greek philosopher tried to justify his viewpoint on Oedipus Rex as the best possible sort of tragedy. Aristotle conjectured that Peripetea can achieve its full effect in tragedy, when it is combined with a sense of epiphanic discovery "for the most poignant tragedy of Human life is the work of human blindness - the Tragedy of Errors" (Frank L. Lucas 98). Also, Anagnorisis is "the Greek word for recognition or discovery" which denotes "the turning point in a drama at which a character (usually the protagonist) recognizes the true state of affairs, having previously been in error or ignorance" (Baldick 10).

\section{Narrative Structure and the Importance of Peripeteia}

In its classical and prevalent definition, narrative structure is considered as something "trajectory," filled with subplots, which all the actions and sequences would rise to a certain culmination, and revolving around the central point (conflict) of the narrative, until the complications subside or resolve in the finale. This "central point ... which the narrative structure pivots" around "is the peripeteia, and the nature, placing and stylistic marking of this turning-point determines the nature of the conflict, whether on a physical, psychological or moral level" (Childs and Fowler 150). Also, Bruner Postulates that "in the deepest sense ... a principal function of narrative is to explore alternative versions of the human condition, 'possible worlds' as it were. It is the vehicle par excellence for exploring troubles and the possible ways of coping with them." Thus "it is no accident that the peripeteia is the "engine' of narrative" (58).

\section{Reading The Unconquered in the light of Hans's Peripeteic Downfall}

The Selected Short Story, the Unconquered, "initially published in Collier's Magazine in 1943 and included in the collection Creatures of Circumstance. This proved to be Maugham's only story set in World War II" (Rogal 288). Set 
in the occupied France, the Narrative commences with the arrival of two German soldiers, Hans and Willie, at a French farmhouse near Soissons. After the soldiers forced their way in; they get drunk, and Hans defiles the Farmer's daughter, Annette Périer. The first peripeteic instance in the narrative -happening even before Freytag's initiating event ${ }^{i}$ is the occupation of France by the Germans; thus, perspicacious Maugham, measuredly, picks out the defeated France as the setting, to signal his reader that the narrative is going to utilize peripeteia as its overriding literary device. The second "reversal in fortune," also, happens to Annette, as she is molested by Hans. Base on the occupied conditions of France, Annette's molestations makes her fortune from "bad to worse."

"Three months" after the assault, Hans finds "himself in Soissons again," and it occurs "to him that it would be fun to go and have a look at the girl he'd had" (Maugham 177). ${ }^{\text {ii }}$ Little by Little, Hans grows fond of Annette, and begins to see her delicacy and grace; he tries to impress her by providing for her family, but Annette still loathes him for what he has done to her. Instead of ignoring Annette, Hans thinks "of her quite a lot. It" tantalizes "him that she should have such a loathing for him" (179). In this way, Maugham, little by little, prepares the stage for the cosmic-peripeteic trajectory downfall of Hans in the narrative; as Schärfe pinpoints: "common to peripeteic upheavals is that they are beyond control of the characters that experience them, brought about by greater forces, and framed by the mimetic effort of the narrative" (104). Yet, the cosmic irony would not easily let go of Hans' kismet; in a moment of anagnorisis, Hans becomes dumbfounded, as it is unfolded that Annette has become impregnated as the result of their first encounter: "she pulled her dress tight and showed herself to him. He couldn't believe his eyes. What he saw caused such a convulsion in his soul as he had never known. The blood rushed to his cheeks. 'You're pregnant"' (181).

When Hans returns to barracks at Soissons that evening, he goes straight to bed but he cannot "get to sleep for hours. He could think of nothing but Annette and her swollen body ... It was his child she bore in her womb." Hans starts "to feel drowsy, and then with a start he" is "once more wide awake, for suddenly it" comes "with the shattering suddenness of gun-fire: he was in love with her" (181). In the following days, Hans traverses from the barracks to the farmhouse ad nauseam, in order to persuade Annette to marry him. Particularly, in one of these confrontations, Hans seeks forgiveness for his earlier misconduct: “'I don't know quite how to begin. I'm sorry for what I did that night, Annette. It wasn't my fault, it was the circumstances"” (183). Here, interestingly, the sheer witticism of Maugham, and his articulator, becomes both piquant and ironic. Piquant in a sense that Maugham is alluding to the title of his collection; and ironic in a sense that Hans blames circumstance instead of Himself. But, actually, Charles Lee does not fall for this false excuse, and catches Hans red-handed. Lee asserts that, in the collection "The characters are creatures of circumstance. But they are more than automatons: they provide causes as well as respond to effects. They make circumstances" (372).

When Hans becomes aware of the death of Annette's beau, Pierre Gavin, in a prison in Germany, he believes that, now, he has the upper hand for marrying Annette, as his chances are escalated. With the promise of fortune and succour, Hans convinces the Périers to talk some sense into Annette. He considers Annette's parents as a lever to achieve success; and, indeed, the dramatic peripeteia of the dénouement revolves around the pivot of Hans's love for Annette (his blindness, his hope for success, and above all, his excessive vanity). Donald William Lucas noted that the dramatic function of peripeteia is heavily depending upon the karmic consequences and protagonists' hopes for eventual triumph; he writes: "A man thinking himself in a good position and in a fair way to succeed in his intentions finds himself, as a natural consequence of previous events, in peril and faced with disaster" (57).

Anyway, Hans and the Périers, still, persist to convince Annette to acquiesce to Hans's proposal of marriage. Two notable conversations occur on this account; in the first instance, monsieur Périer summons the logic: "we've been defeated and we must accept the consequences. We're got to make the best arrangement we can with the conquerors" (187). However, it does not seem that exploiting logic has any effect on Annette, as she still persists on her earlier remarks: "I hate him [Hans]. I hate his vanity and his arrogance. I could kill him: his death wouldn't satisfy me. I should like to torture him as he's tortured me. I think I should die happy if I could find a way to wound him as he's wounded me" (187). On the second occasion, Hans approaches with sentiment: "That child that's going to be born means everything in the world to me. Oh, I don't know how to put it; it's put feelings in my heart that I don't understand myself" (189). However, Annette still remains antipathetic as she retorts to Hans: "You are my enemy and you will always be my enemy" (189).

Later, close to the dissolution of the narrative, Hans stops by the farmhouse, and to his amazement, he was apprised of Annette's earlier parturition: "The baby was born this morning. It's a boy" (190). Hans rejoices with such remarks as "Oh, my God, I'm so happy," and "How beautiful the world is! I want to see Annette" (190). Hans's latest demand gives on to the paradoxical-climactic dénouement. Madame Périer goes upstairs to inform Annette of Hans Arrival, but soon she vociferates that the mother and the newborn are not in the upstairs' room: “'They're not there. She isn't in her room. The baby's gone"” (191). It appears that Annette has taken the baby, and absconded from the farmhouse through the "storeroom." Hans is determined to find the baby and Annette no matter what, but as he opens the door, he sees Annette's weary figure who is approaching the house:

Hans flung open the door, and as he did so Annette walked in. ... She was deathly white. Madame Périer sprang towards her and took her in her arms. 'Where have you been? Oh, my poor child, you're wet through. What madness!'

But Annette pushed her away. She looked at Hans. 'You've come at the right moment, you.'

'Where's the baby?' cried Madame Périer. 
'I had to do it at once. I was afraid if I waited I shouldn't have the courage.'

'Annette, what have you done?'

'I've done what I had to do. I took it down to the brook and held it under water till it was dead.'

Hans gave a great cry, the cry of an animal wounded to death; he covered his face with his hands, and staggering like a drunken man flung out of the door. Annette sank into a chair, and leaning her forehead on her two fists burst into passionate weeping. (191)

The Unconquered's dramatic ending becomes a proof for the locus classicus that "a peripeteia occurs when a course of action intended to produce a result $x$, produces the reverse of x" (Frank Laurence Lucas 96). Frank Lucas reckons, it is no coincidence that Aristotle puts Peripeteia and Anagnorisis alongside each other, in view of the fact that he, simply, wants to accentuate on the "irony of human blindness." Hans who sees himself as a conqueror, allows himself to venture in territories which are out of his control. His "blindness" can be regarded as the self-indulgent egomania which is resulted from the conditions which happen during wars, when the conquerors fail to see the defeated as a true human being and their equals; thus, instead of seeing the Périers as compeers, Hans's ego creates an animal kingdom of "the farmhouse," and whenever he feels his domination is threatened by the Périers, he stifles them by giving away day-to-day provender. Although Annette's parents have succumbed, but as an educated person, she cannot accept such animalistic conduct, ergo, her feeling of abhorrence for Hans takes a serious turn on the newborn; thus, this would become the only way for Annette "to wound him [Hans] as he's wounded" her.

The cosmic-peripeteic element has been foregrounded in the ending for sure; because "the peripeteia, in short, is the working in blindness to one's own defeat: the anagnorisis is the realization of the truth, the opening of the eyes, the sudden lightening-flash in the darkness" (Frank Laurence Lucas 99). Hans who has been having an animalistic behavior towards the defeated throughout the narrative, like a sudden lightening-flash, realizes the truth; thus, his eyes would become open towards the truth and, interestingly, he, who thought of himself as the vanquisher of the animal kingdom, would be rendered by Maugham to experience a reversal in fortune and, bafflingly, he himself becomes an animal wounded to death.

\section{A Fortune Reversed}

The Unconquered is only one instance, amongst many, which exhibits Maugham's excessive preoccupation with the exploitation of dramatic devices in his short fiction. Maugham fiction, in general, are heavily saturated with peripeteic moments. As it is observed, the whole narrative structure of the Unconquered lingers on Hans's unreciprocated love towards Annette, but in the end, not only Hans could not compensate for his earlier misconduct, but also he loses his own child. And, to me, Maugham is exactly follows the Aristotelian tradition of tragedy, because both peripeteia and anagnorisis happen at an instant, and walk shoulder to shoulder towards the finale.

\section{References}

Baldick, Ch. (2001). “Anagnorisis.” The Concise Oxford Dictionary of Literary Terms. Oxford: Oxford University Press. 10. Print.

Bruner, J. (2005) "The Reality of Fiction". McGill Journal of Education / Revue des sciences de l'éducation de McGill 40.1 (Special issue on Narrative Matters): 55-64. Print.

Childs, P. \& Fowler, R. (2006). "Narrative Structure.” The Routledge Dictionary of Literary Terms. London: Routledge. 150-151. Print.

Hanson, C. (1985). "The Tale-Tellers: I". Short Stories and Short Fictions, 1880-1980. 1st ed. London: Palgrave Macmillan. 34-54. Print.

Lee, Ch. (1997). "Mr Maugham, Still Urbane." W. Somerset Maugham (Collected Critical Heritage). Ed. Anthony Curtis and John Whitehead. New York: Routledge. 371-72. Print.

Lucas, D. W. (1962). "Pity, Terror, And Peripeteia". The Classical Quarterly 12.1: 52-60. Print.

Lucas, F. L. (1962). "Plot." Tragedy: Serious Drama in Relation to Aristotle's Poetics. New York: Collier. 81-106. Print.

Maugham, W. S. (1988). "The Unconquered". W. Somerset Maugham Sixty-Five Short Stories Complete \& Unabridged. William Somerset Maugham. 1st ed. London: Octapus/Heinemann Ltd. 174-191. Print.

Quinn, E. (1999). "Peripeteia." A Dictionary of Literary and Thematic Terms. 2nd ed. New York: Facts On File. 318. Print.

Rogal, S. J. (1997). “The Unconquered.” A William Somerset Maugham Encyclopedia. Westport, Conn.: Greenwood Press. 288. Print.

Schärfe, H. (2008). "Narratives That Move". Persuasive 2008: The Third International Conference on Persuasive TechnologyOulu, Finland - June 4-6, 2008 Poster Proceedings. Oulu University Press. 102-105. (University of Oulu. Department of Information Processing Science. Series A, Research Papers).

\section{Notes}

${ }^{i}$ For further readings please see: Freytag, Gustav and Elias J MacEwan. Freytag's Technique of the Drama. St. Clair Shores: Scholarly Press, 1969. Print.

${ }^{\text {ii }}$ Henceforth, to avoid prolixity, the last name of the author will be removed from the parenthetical citations. 